\title{
LAND USE ON CAPE BARREN ISLAND, TASMANIA
}

\author{
by R. A. Perrin \\ (with six text-figures)
}

PERRIN, R.A., 1988 (31:x): Land use on Cape Barren Island. Pap. Proc. R. Soc. Tasm. 122(2): 73-8.3.

https://doi.org/10.26749/rstpp.122.2.73 ISSN (0)8()-47()3. P.O. Box 76.3, Rockhampton, Queensland. Australia 47(0), formerly University of Tasmania. llobart.

The physical and biological environment of Cape Barren Island is described, the human environment is outlined in terms of past and present patterns of land use, and land use issues are detailed. The island has important biological and historical features, and reservation of certain areas seems warranted. Agricultural developments on the island are severely constrained by the poor soils and isolation from markets, but alternative developments such as aquaculture and wilderness conservation appear feasible. Tasmanian Aboriginals at present claim extensive land rights on the island and the resolution of these claims is necessary if a land management plan for the island is to be successfully implemented.

Key Words: Cape Barren Island, land use, aquaculture, wilderness conservation.

\section{INTRODUCTION}

Cape Barren Island lies about $20 \mathrm{~km}$ off the northeastern coast of Tasmania and, like many other islands in the Bass Strait region, remains relatively undisturbed. There have been few land use developments on the island, primarily due to its remoteness and poor soils, but with increasing pressure for farmland and tourism destinations this situation is likely to change.

If changes in land use are unplanned, there is a danger that the unique environment and special historical and biological importance of Cape Barren Island will be degraded. There has been a call for the production of a management plan for the island (Allen et al. 1978) but this is yet to eventuate.

The aim of this paper is to bring together the basic information on the physical, biological, and human environment of Cape Barren Island and to introduce the options for future land use. It represents the first comprehensive compilation of information on Cape Barren Island, the data being gathered from published and unpublished papers, letters, interviews, and a trip to the island in October 1985.

\section{PHYSICAL ENVIRONMENT}

\section{Topography and Climate}

Cape Barren Island, located south of Flinders Island, is the second largest island in the Furneaux Group, with an area of $445 \mathrm{~km}$ (fig. 1). It is a high, rugged island with a much indented coastline and offers visitors spectacular coastal panoramas.
Granite underlies most of the island and in places forms peaks exceeding $500 \mathrm{~m}$ in height. The Mount Munro range in the northwest runs east-west across the island for approximately $10 \mathrm{~km}$ and culminates in Mount Munro $(687 \mathrm{~m})$ (fig. 2). The Mount Kerford range in the southeast runs north-s uth for approximately $10 \mathrm{~km}$ and peaks at Mount Kerford $(503 \mathrm{~m})$. Two other significant peaks are Double Peak (512 m) and Hogans Hill (392 m) (Blake 1947).

On the eastern side of the island there is a low-lying coastal plain, from Puncheon Point in the north to Cape Barren in the south, comprising about $20 \%$ of the land area. In places sand dunes have altered drainage patterns and formed lagoons which parallel the coast. On the western side there is a slightly elevated undulating plain extending from Sandford Bay on the north coast to Thunder and Lightning Bay on the south coast.

Drainage is mainly via short crecks arising in the high inland areas. Most of the creeks flow either north or south directly to coastal bays via broad low-lying valleys (Pinkard \& Richley 1982).

Information on the climate of Cape Barren Island was derived from the records of the Burcau of Meteorology, Hobart. Rainfall data were collected on Cape Barren lsland, wind and temperature data at Pats River. Flinders Island.

Cape Barren has a temperate maritime climate. The average annual rainfall is $710 \mathrm{~mm}$ and precipitation is greatest in winter (fig. 3). The island experiences generally mild and even temperatures with a maximum in February and a minimum in July. The prevailing wind directions are westerly and northeasterly. 


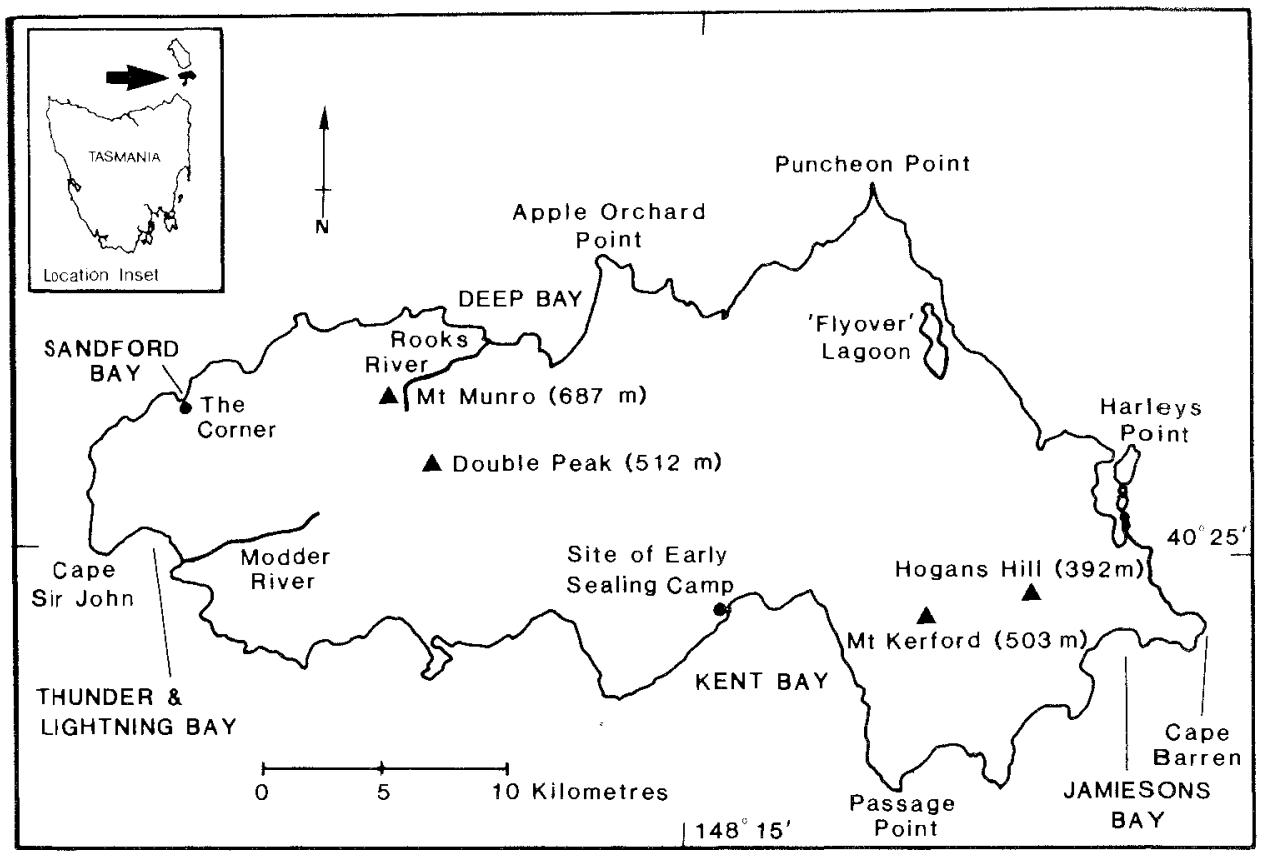

FIG. 1 - Cape Barren Island.

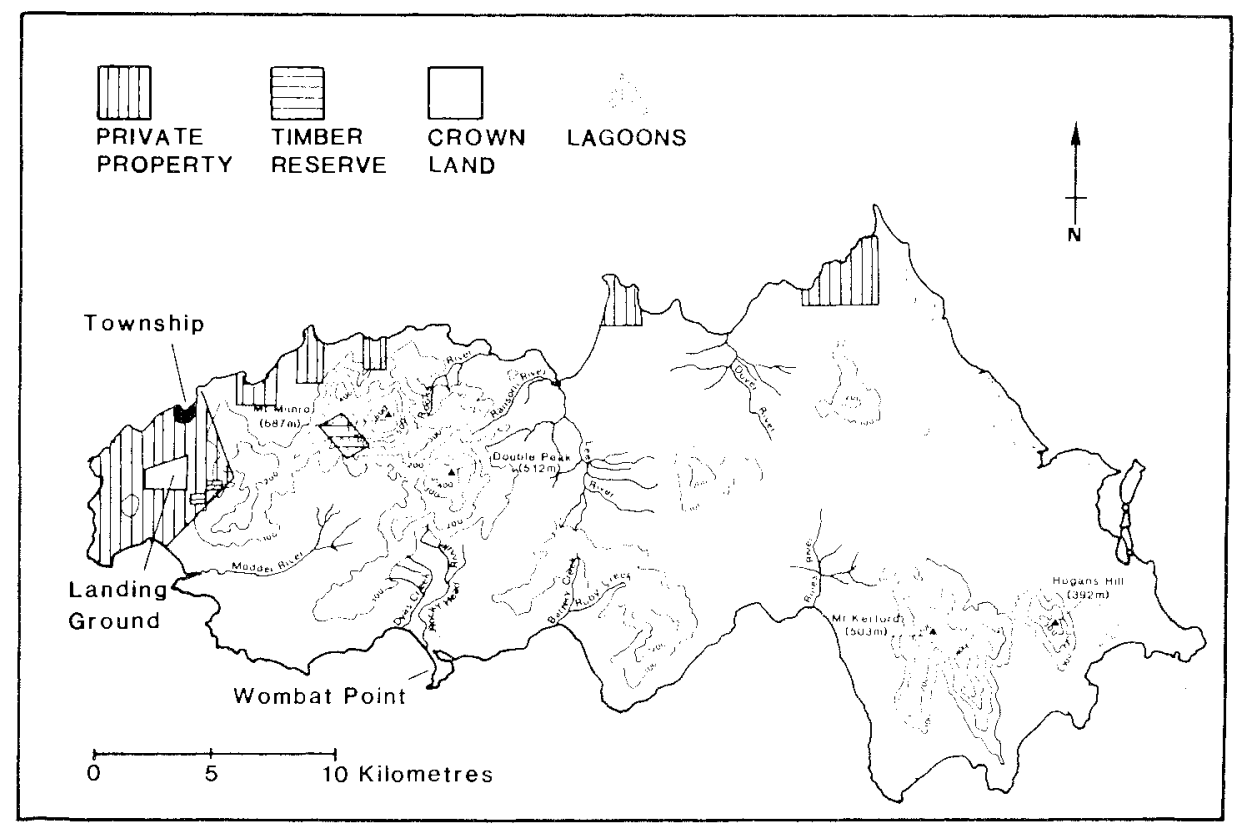

FIG. 2 - Topography and land tenure of Cape Barren Island (after Tasmania 1:100 000 Topographic Map Land Tenure Index Series, edition 2, Flinders Island Special. Lands Department, Hobart, 1983 ). 

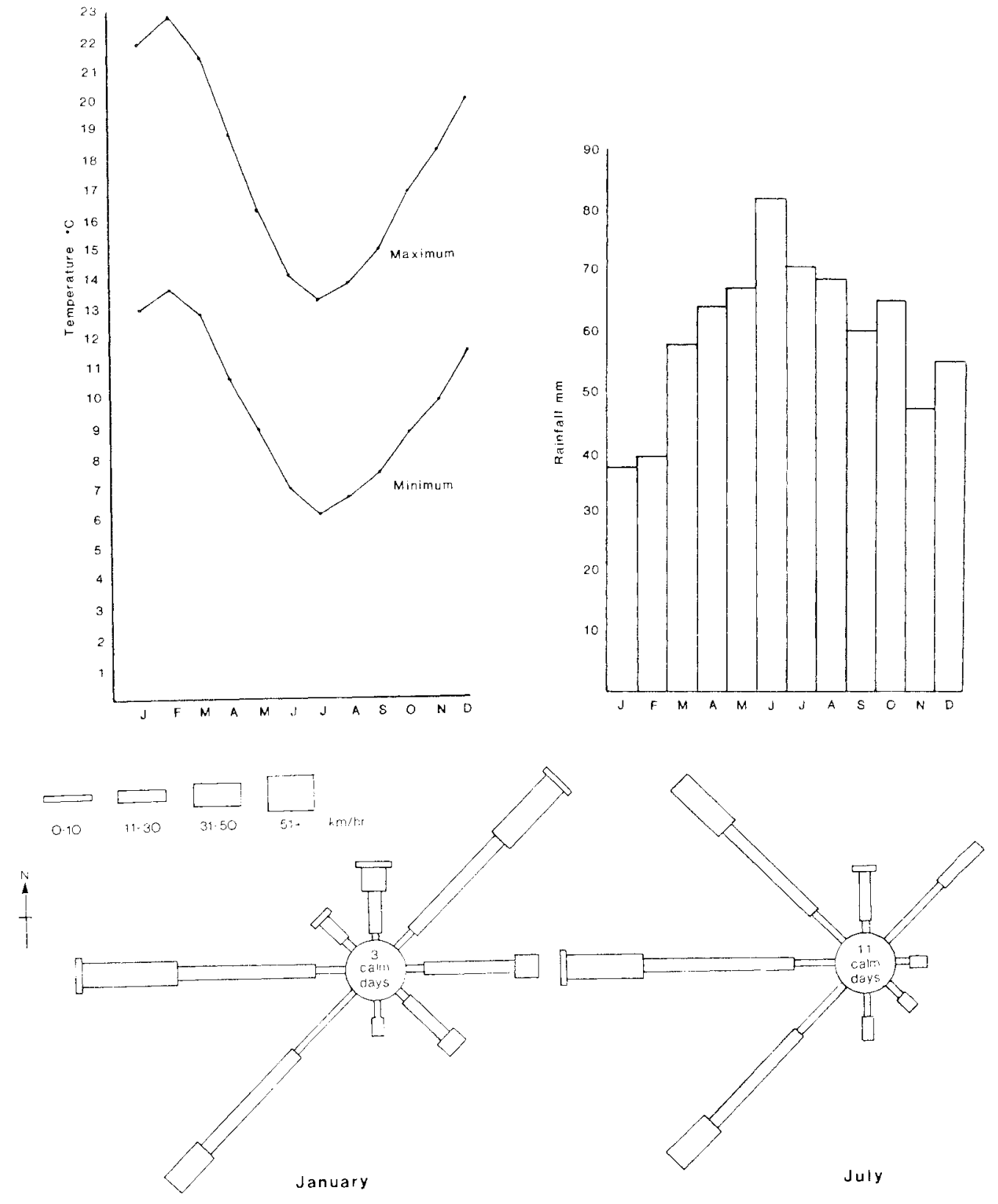

FIG. 3 - Climatic information for Cape Barren Island. 


\section{Geology and Minerals}

The geology of Cape Barren Island is similar to that of northeastern Tasmania and Wilsons Promontory in Victoria (E.J. Reid, pers. comm.).

The oldest rocks on the island are the Mathinna Beds (metamorphosed, complexly folded beds of sandstones and siltstones) probably of Devonian age, occurring in an east-west tract from Apple Orchard Point on the north coast, towards Harleys Point on the east coast. Shore outcrops occur at Thunder and Lightning Bay in the northwest (fig. 4).

The Mathinna Beds have been intruded by granite and granites now underlie or are exposed over much of the island. Eleven distinct granitoid plutons were recognised by Cocker (1980) on the basis of their mafic mineralogy. In places the granites have been invaded by dolerite dykes.

Tertiary deposits on the island include calcareous sandstones and limestones of Miocene age, notably in the vicinity of The Comer (the island township) and the lowlands of western Cape Barren Island, and fluviatile tin-bearing sediments, occurring most frequently in the low areas of the island. There is a small, isolated outcrop of Tertiary basalt occurring at Lascar Point on western Cape Barren Island (Cocker 1980).

Quaternary sediments on the island consist of aeolian deposits, marine sediments, and alluvium (Goscombe 1965). There are long attenuated sand dunes, oriented in the direction of the prevailing wind in many low-lying coastal areas. Sandy sediments occur over much of the coastal areas of the island. The most recent developments include transverse dunes at Thunder and Lightning Bay and Deep Bay, lunettes on the eastern side of the island, and a $0.3-1 \mathrm{~m}$ veneer of alluvium and topsoil which blankets the valleys (Goscombe 1965).

Traces of gold, graphite and molybdenum (Blake 1947), topaz (Cocker 1980), amethyst, garne1, opal, marcasite, rutile and quartz (Matthews 1981) have been identified on the island. Some interest is current in the heavy-mineral content of beach and inland dune sands, in particular zircon. rutile and monazite (for its content of rare-earth minerals) (D. Jennings, pers. comm.).

The only mineral extracted from Cape Barren Island in the past was alluvial tin but poor values, impurities, difficult extraction conditions, and lack of an adequate water supply hampered production. The small scale, the isolation, and the depressed tin markets make tin mining uneconomic at the present time.
Soils

This section is derived from the work of Pinkard \& Richley (1982), who, on the bases of topographical, climatic and geological data, divided Cape Barren Island into a series of land systems. The soil descriptions are thus a broad overview of soil types in each of these land systems.

On the eastern, southern, and parts of the western areas of the island the soils are deep with ridges of pale yellow sand, sometimes in the form of low coastal dunes (fig. 5). The sand soil on the flats has an iron organic layer at depth, while the sands on the gently sloping plain are mottled. In the central parts of the island there are large areas of stony and gravelly soils, with rock outerops occurring frequently. In places the granite soils are overlain by windblown sand. In the Lec River and Dover River areas (fig. 2) there are rock outcrops on the crests and upper slopes. Duplex soils are found on the mid-slopes while clay soils are found on the lowest areas. On the extreme eastern coastal area and at places along the northern coast, deep sand soils have developed. The calcareous sands close to the beaches are undifferentiated and are subject to wave erosion. In the area around Mount Munro mottled duplex soils are encountered. The surface soil is gravelly, while red mottlings are evident at depth, particularly in the soils on the crests and steep upper slopes.

Viewed overall, the island's soils are poorly developed and this has severely constrained agricultural development (P. Warren, pers. comm.).

\section{BIOLOGICAL ENVIRONMENT}

\section{Vegetation}

The vegetation shares affinities with both the Tasmanian and Australian mainlands and consists largely of coastal heathlands with smaller areas of dry sclerophyll forest and woodland. Many areas have been affected by repeated scrub fires, resulting in an immature vegetation and a predominance of the grasstree (Xanthorrhoea australis R. Br.) (Whinray 1977) with an understorey of shrubs and sedges (Kirkpatrick 1977). Significant land clearing has occurred in the vicinity of Puncheon Point, Apple Orchard Point, and on the western side of the island, near The Corner.

In the lowland portions of the island there are large areas of heath (fig. 6). In the drier areas of the lowlands, the larger species are the Smithton 


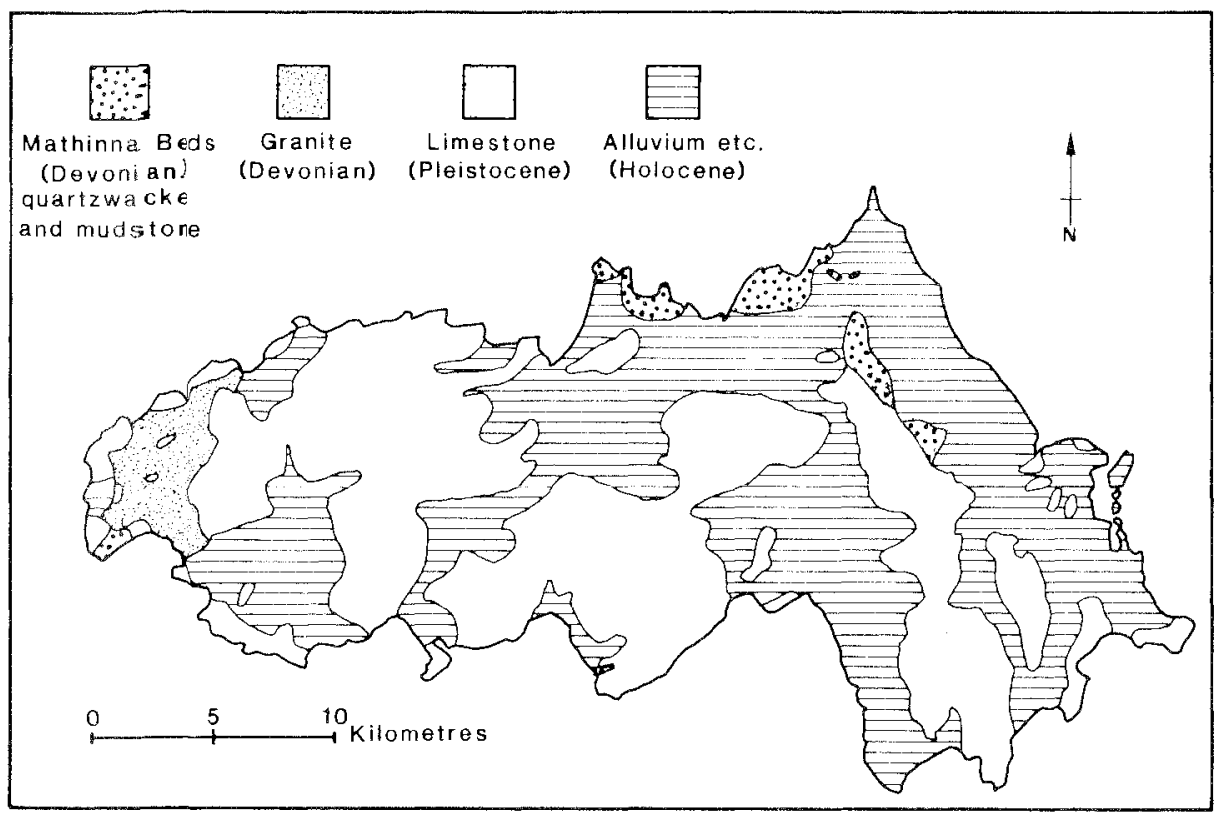

FIG.4-Geology of Cape Barren Island (after Geological Map of Tasmania 1:500 000. Department of Mines, Tasmania 1976).

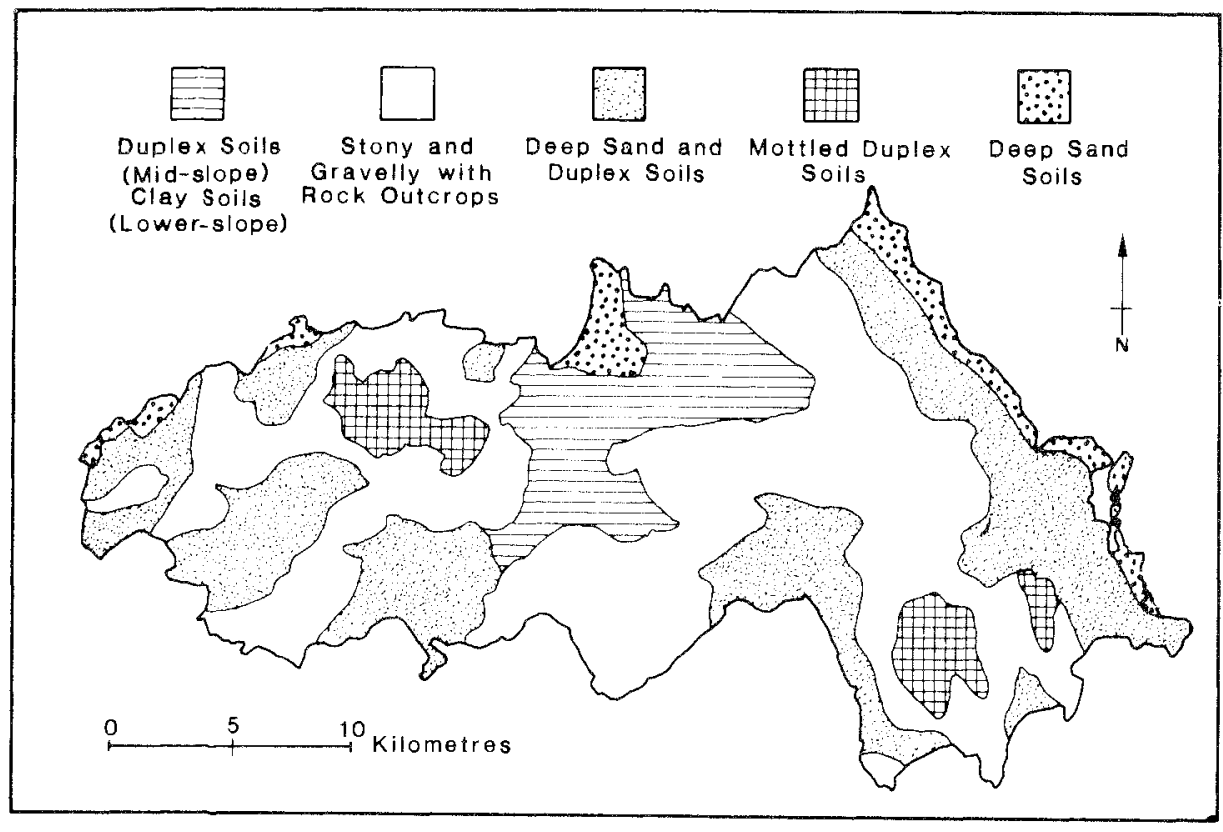

FIG. 5 - Soils of Cape Barren Island (after Pinkard \& Richley 1982). 


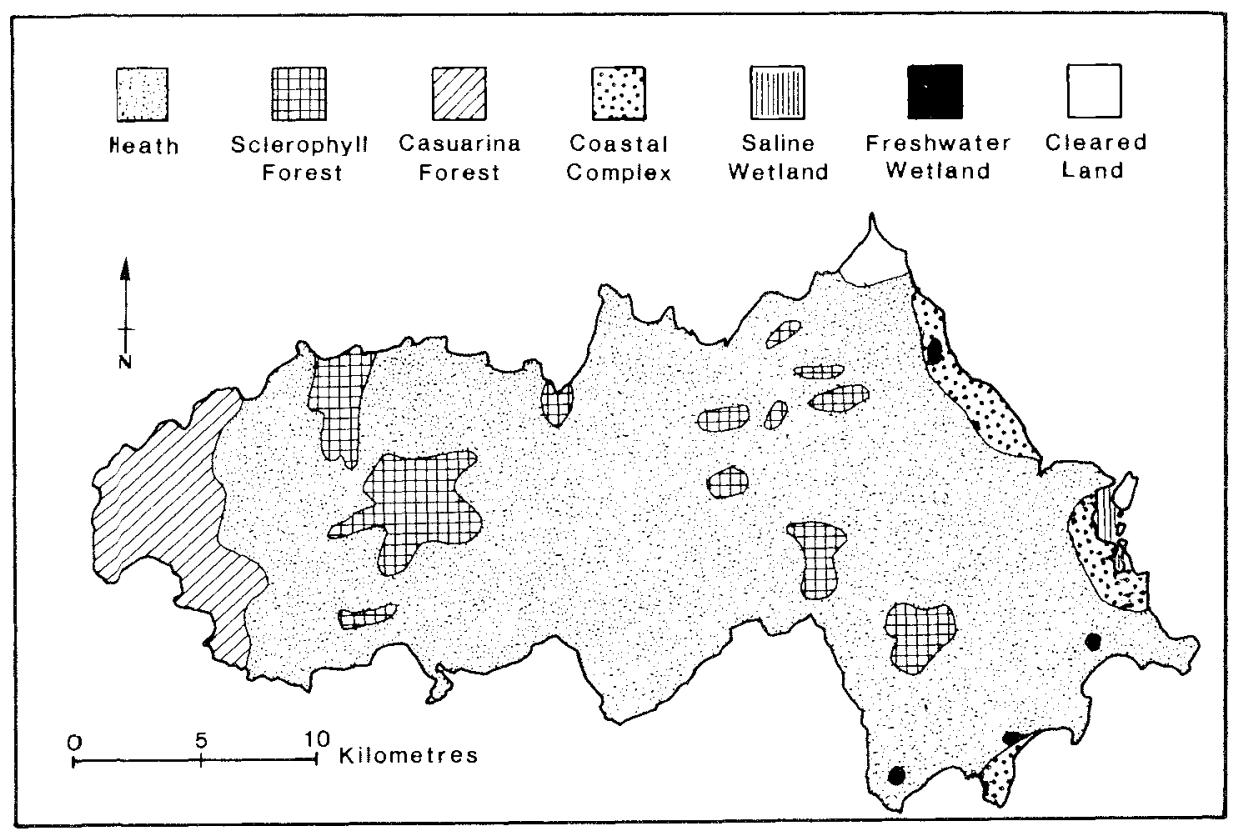

FlG. 6-Vegetation of Cape Barren Island (after Kirkpatrick \& Dickenson 1984).

peppermint (Eucalyptus nitida Hook. f.), the grasstree (Xanthorrhoea australis), silver banksia (Banksia marginata Cav.) and the Tasmanian teatree (Leptospermum glaucescens S. Schauer). The smaller species in the drier areas include wiry bauera (Bauera rubioides Andr.), swamp beardheath (Leucopogon esquamatus R. Br.), guinea flower (Hibbertia procumbens (Labill.) DC.), and hairy boronia (Boronia pilosa var. laricifolia Hook. f.). Common herbs in these areas include bogrush (Schoenus turbinatus (R. Br.) Poir), climbing sundew (Drosera planchonii Hook. f.), and the slender bogrush (Schoenus tenuissimus Benth.) (Whinray 1977).

In the wetter areas of the lowlands there are scented paperbarks (Melaleuca squarrosa Donn. ex Sm.), swamp paperbarks (M. ericifolia Sm.), and manuka (Leptospermum scoparium J.R. and G. Forst.). Smaller species include the largeflowered rapier sedge (Lepidosperma forsythit A.A. Hamilton) and the pink swampheath (Sprengelia incarnata Sm.) (Whinray 1977). There are also a number of herbs in these areas, such as the angled lobelia (Lobelia alata Labill.) and the tufted centrolepis (Centrolepis fascicularis Labill.) (Whinray 1981).
In the higher areas, such as Mount Munro and Mount Kerford, there are small outcrops of eucalyptus forest, survivors of the frequent scrub fires. These forests contain the manna gum (Eucalyptus viminalis Labill.) and the blue gum (E. globulus Labill.). The manfern (Dicksonia antarctica Labill.), dogwood (Pomaderris sp.) and blackwood (Acacia melanoxylon R. Br.) are commonly found in the understorey.

Salt marshes are found on the extreme eastern margins of the island. These marshes usually include species such as Cotula reptans Benth., Eryngium vesciculosum Labill., Juncus krausii Hochst., and Sellieria radicans Cav. (Kirkpatrick \& Glasby 1981).

Cape Barren Island has a number of rare and/ or poorly reserved species and communities of plants. The importance of the island's flora is examined in the conservation section.

\section{Fauna}

Early reports of visits to the Furneaux Group by naturalists make no mention of Cape Barren Island (Gabriel \& Campbell 1894, Le Souef 1929. McKay 1955) and data on its mammals were not 
collected until 1969 (Whinray 1971, Hope 1973). Bird data have been collected during short visits to the island (Guiler 1961, Whinray 1970, Abbott 1972, D. Milledge, pers. comm., P. Duckworth, pers. comm., P. Brown, pers. comm.).

Five native mammals have been recorded on the island, and a further four species have been found in fossil deposits. The five extant mammals are the brush wallaby (Macropus rufogriseus Desmarest), the pademelon (Thylogale billardierii Desmarest), the ringtail possum (Pseudochcirus peregrinus Boddaert), the echidna (Tachyglossus aculeatus Shaw \& Nodder) and the eastern swamp rat (Rattus lutreolus Gray). The four mammals recorded from fossil deposits are the potoroo (Potorous apicalis Gould), the tiger cat (Dasyurus maculatus Kerr), the brown bandicoot (Isoodon obselus Shaw \& Nodder) and the wombat (Vombatus ursinus Shaw). Introduced mammals on the island include the house mouse (Mus musculus Linnaeus), ships rat (Rattus rattus Linnaeus) and the domestic cat, dog, sheep, cow, horse and goat.

There are 71 bird species recorded from the island (Guiler 1961, Whinray 1970, Abbott 1972, P. Brown, pers. comm., P. Duckworth, pers. comm., D. Milledge, pers. comm.). The Cape Barren Goose (Cereopsis novae-hollandic Latham) has been recorded as occurring on the island (Guiler 1961) but not breeding successfully there (G. Hocking, pers. comm.). The occurrence of the tawnycrowned honeyeater on the island is particularly noteworthy as it has a very restricted distribution in Tasmania (P. Brown, pers. comm.)

Collections have been made of land and freshwater snails (Smith \& Kershaw 1981), centipedes (Mesibov 1986), spiders, praying mantis and land planarians (R.H. Green, pers. comm.).

Overall, the faunal assemblage, especially the invertebrates, remains poorly studied (R.H. Green, pers. comm.)

\section{HUMAN ENVIRONMENT}

\section{Historical Perspective}

As yet there is no evidence of pre-European occupation of Cape Barren Island by Aboriginals, although it is known that there were Aboriginals living on Flinders Island approximately 7000 years ago (Orchiston \& Glennie 1978). The first documented settlement of Cape Barren Island occurred at Kent Bay (fig. 1) in 1798 with the establishment of the headquarters for an English sealing operation (Cumpston 1973). For a short while it was the third largest settlement in Australia (behind Sydney Cove and Norfolk Island), and it preceded the Risdon Cove settlement in southern Tasmania by four years. It is not clear for how long the Kent Bay settlement was occupied, but seals were still being harvested there in 1810 (Cumpston 1973).

The next phase of settlement on the island was by the descendants of European sealers and their captured Aboriginal "wives"(collectively termed "islanders"). The islanders also inhabited many of the other islands in the Furneaux Group but it seems they were displaced from them when the Government annexed the islands for sale or lease as farmland. Many of these displaced islanders had settled on Cape Barren Island by the 1870 's (Murray-Smith 1973). In 1881 the islanders were given exclusive use of (but not title to) a 2400 ha land reserve on the western side of Cape Barren Island (Meston 1947). However, agricultural practices did not develop at this stage, and the islanders relied heavily on hunting mutton birds (Puffinus tenuirostris Temminck) for food and income (Allen et al. 1978).

Tin was reported from Cape Barren Island in 1871 and mining commenced at Rooks River (fig. 2) in 1882 (Goscombe 1965). Mining was confined mostly to the Rooks River and Modder River areas and apparently never reached a large scale due to the lack of water for the tin extraction process. Small-scale mining continued in the Rooks River and Modder River areas at least until the mid1930's.

Further interest in the minerals of the island was shown by large mining companies during the 1960's. In 1965 the Utah Development Company initiated a geological reconnaissance of the Furneaux Group, with particular emphasis on tin extraction in the Rooks and Modder River areas (Volker 1968). In 1968 Broken Hill Proprietary and Utah began a joint offshore drilling programme to explore for tin in Deep Bay (fig. 1). Both of these programmes proved unsuccessful due to low concentrations of tin. In 1972 Blue Metal Industries continued to prospect for tin in the Rooks and Modder River areas but failed to locate tin in commercial concentrations and the programme was abandoned (Standard 1970).

\section{Current Land Ownership and Use}

The Department of Lands, Parks and Wildlife has control over most of the 44500 ha on the island, its areas of control being unallocated Crown Land (35 200 ha), leasehold land (6900 ha) and Coastal Reserve (approximately 100 ha). 
The major private holdings of land consist of two farms, one on the extreme western side of the island (the Modder River Station), and the other on the northeastern end of the island, close to Punc heon Point. In addition, there are a number of small farms and residential blocks near The Corner and along the northwestern coast. Of the total island area of 44500 ha, only 2300 ha $(5.2 \%)$ are unde $r$ private ownership. No more Crown Land will be sold, as an embargo was placed on such sales by the Tasmanian Government in July 1985.

The Forestry Commission has a 133 ha timber reserve in the vicinity of Mount Munro, but the reserve is not under active management by the Commission.

No areas are reserved under the National Parks and Wildlife Act 1970 on Cape Barren Island but there are some wildlife sanctuaries, nature reserves, and one historic site on some of the small islands near Cape Barren Island. Some reservation under that Act is considered warranted because of the island's heathlands and wetlands and the historic site of the early sealing operations at Kent Bay (P. Bosworth, pers. comm.).

\section{LAND USE ISSUES}

\section{Land Rights}

Land rights issues date back to the late 1860 's when Cape Barren Islanders petitioned the Government to reserve some of the smaller islands in the Furneaux Group for mutton birding (Meston 1947). In 1881, 6000 acres (2430 ha) of land were reserved for the exclusive use of the islanders and in 1912 the Government passed the Cape Barren Island Reserve Act (Tasmania) 1912 which gave the islanders an opportunity to each lease 20 ha of land with a 99-year tenure. The Act expired in 1951 and some islanders took out further leases around The Corner township.

Since that time there have been further claims for land rights for Tasmanian Aboriginals which have involved areas of Cape Barren Island. However, the current land rights issue first gained prominence in 1973 as part of a growing national awarcness of the rights of Aboriginals (C. Fulton, pers. comm.). The inception of the Tasmanian Aboriginal Centre in 1973 resulted in renewed approaches to Government for the setting aside of areas of Tasmania for Aborigines. In 1977 a petition by Tasmanian Aboriginals for land allocations resulted in the establishment of an Aboriginal Affairs Study Group in April 1978 by the Government (Allen et al. 1978). The Study Group recommended that a Lands Trust be set up comprising a committee drawn from Aboriginal organisations in Tasmania. Further, it recommended that all of Cape Barren Island, with the exception of the existing freehold and lease areas, be vested with the proposed Lands Trust and that the rent from existing leases go to the Trust. The Trust would be cmpowered to grant leases of istand land for up to 99 years, preferably to existing Aboriginal residents and with the permission of the Cape Barren Island Council.

The study group also reconmended:

"... that all such leases be granted only in accordance with a general management plan for Cape Barren Island which would preserve the major part of its unique wilderness area of coastal heathland while allowing hunting by accepted practices..." (Allen et al. 1978).

None of the recommendations of the Aboriginal Affairs Study Council have been imple mented.

Since 1978 a Tasmanian Aboriginal Lands Council Bill has been before Parliament which seeks to vest control of certain lands with a council consisting of adult members of the Tasmanian Aboriginal Centre Inc. Amongst other areas, 35000 ha on Cape Barren Island are listed for control by the council (Tasmanian Aboriginal Land Council Bill 1987). The Bill specifies that the council shall hold, develop and manage land on behalf of Tasmanian Aboriginals. In particular, the council would have the right to review, cancel or renegotiate any existing Crown leases. Further, the taking of any wildlife from land vested in the council would be legal, for Aboriginals, providing the wildlife is not endangered in terms of the National Parks and Wildific Act 1970.

Obviously this Bill, if implemented, would have far reaching effects on land use patterns on Cape Barren lsland. As yet the Bill remains unpassed. Clearly the land rights issue is in need of resolution before long-term land management decisions can be made.

\section{CONSERVATION}

Cape Barren Island has been found to contain important vegetation communities and species and, in particular, the extensive heathlands are considered to be areas of high conservation value. The heathlands were examined as part of a Tasmania-wide study which revealed that of the 
nine heath communties identified on Cape Barren Island, the dominant community was poorly reserved in State Reserves. It was stated that the conservation of the dominant community was urgent (Kirkpatrick 1977).

In addition, some 200 ha of the island's wetlands were surveyed and were also found to contain species and communities which were unreserved or poorly reserved throughout mainland Tasmania. In particular, five species and two communities were considered in need of reservation (Kirkpatrick \& Harwood 1983). Further, $42.3 \mathrm{~km}$ were nominated and accepted for inclusion on the list of Wetlands of International Importance Especially as Waterfowl Habitat (WIIEWH), under the Ramsar Convention, to which Australia is a signatory (Blackhall 1986).

In the eastern part of Cape Barren Island there is a large area of Crown Land which has remained unexploited by humans. The vegetation of this area has been degraded by the recurrent scrub fires on the island but contains 12 plant species found on mainland Australia but not on mainland Tasmania, and is thus of considerable biogeographic significance. As well, this area houses the rare bog club moss (Lycopodium serpentinum Kunze in Lehm.) and may prove to be the Australia-wide stronghold for this species (Whinray 1977).

In 1979 a survey tean reported on wilderness in Tasmania to the Australian Heritage Commission. In its findings the survey team recommended that the "wilderness" area of Cape Barren Island, including offshore rocks and islands, was worthy of protection (Russell et al. 1979:67 ef seq.).

Studies have been conducted on waterbird habitat on Cape Barren Island as part of a National Parks and Wildlife Service (NPWS - now incorporated into the Department of Lands, Parks, and Wildlife) survey to determine waterbird usage and the conservation significance of selected Tasmanian wetlands. Seven wetlands were visited, resulting in the recommendation that "Flyover" and other lagoons on the eastern side of the island should have a high conservation priority. The study also stated:

"... It would be highly desirable to reserve the entire coastal complex to Passage Point ... if the Service is unable to do this it is recommended that first priority be given to "Flyover" Lagoon and second to an area from Harleys Point to Jamiesons Bay" (Blackhall 1986).

The NPWS also proposed the reservation of a large area around Kent Bay (the site of early seal ing operations) as an Historic Site but the proposal is yet to be accepted (P. Bosworth, pers. comm.).

\section{AGRICULTURAL/INDUSTRIAL DEVELOPMENT}

Further expansion of agriculture on Cape Barren Island is severely restricted by poor soil development, isolation from markets and a high lire frequency. There remain some unused areas of reasonable grazing land (S. Fuglsang, pers. comm.), but, in the present economic climate, these would allow at most only a few more small farms to become established.

An assessment of the forestry potential of Cape Barren Island was made in 1975 by the Commonwealth Department of Aboriginal Affairs and the Tasmanian Forestry Commission. It was concluded that plantation forestry would be uneconomic in the long term due to the inadequate soil depth and drainage, low soil fertility and rainfall, high salt spray and sea winds, risks of fire, lack of expertise on the island, poor road infrastructure, and isolation from markets (R.N. Parker, pers. conm.). Since this study was made, these factors have changed little and forestry still appears to be uneconomical.

Preliminary investigations into the suitability of the island for aquaculture ventures involved the growing of Pacific oysters (Crassostrea gigas Thunberg) and blue mussels (Mytilus edulis planulatis L.) in the vicinity of The Corner, but the results were inconclusive (D. Wolfe, pers. comm.). However, the aquaculture potential of Cape Barren Island appears to be considerable. There are many bays, inlets and rivers that are likely to be suited for the culturing of species such as oysters, mussels, abalone, scallops and freshwater crustaceans. The low pollution levels of marine and freshwater habitats are an important economic asset for the island, especially as such habitats become scarcer elsewhere in Tasmania.

There has been some interest shown recently in the mining of beach and inland dune sands on the cast coast of Cape Barren Island. The Ytrium Corporation Pty Ltd has applied for an exploration licence to prospect for heavy minerals used in superconductors. At the time of writing no licence had been issued. The proposed area of exploration includes important heath and wetland communities (Kirkpatrick 1977, Kirkpatrick \& Harwood 1983) and areas registered on the list of WIIEWH (Blackhall 1986). 
In the short to medium term, prospects for oil and gas developments in the immediate offshore areas of Cape Barren Island are considered low (P.W. Baillie, pers. comm.).

Although no formal tourist statistics are kept, it is known that about 500 people visit the island during the period October-April each year. They normally arrive by boat or light plane and are selfsufficient as no accommodation cxists for tourists on the island (G. Lloyd-Webb, pers. comm.). In a recent sludy of tourism in the north and northeast of Tasmania, the development of a wilderness lodge was proposed for either southern Flinders Island or Cape Barren Island in the vicinity of Puncheon Point (fig. 1). The study recognised that development constraints on the Cape Barren Island site included indecision on the future management of the island, high costs of construction and maintenance, low water availability, and the shortage of suitable land (Hepper et al. 1987).

Cape Barren Island offers areas suitable for outdoor recreational pursuits such as wilderness trekking or diving-fishing tours. As wilderness areas diminish in Tasmania the potential for recreation based on the Cape Barren Island wilderness increases.

\section{COMMENTS AND CONCLUSIONS}

Future land use decisions affecting Cape Barren lsland need to take into account a number of important environmental and ethnological features. The island retains significant areas of wilderness (if somewhat fire degraded), a rapidly diminishing resource in Tasmania. In addition, it has historic and current cultural importance, being the homeland of many of today's Tasmanian Aboriginals.

Little information exists on the istand's natural history, but what is known shows that the island has several rare or endangered species or communities. Clearly, more researeh into the flora and fauna of the island is needed to document these various communities, prior to any major changes in land use.

The mining of beach and inland dunes of Cape Barren Island would threaten important vegetation and faunal assemblages. As well it would destabilise sand dunes resulting in irreversible damage to wilderness and farmland areas. An examination of the impact of mining, via a comprehensive environmental impact statement, seems warranted.

Cape Barren Island offers wide scope for the establishment of a conservation/wilderness area. Such an area would aid the protection of the rare and endangered flora and fauna of the island, and would help meet Australia's international commitments to the Ramsar Convention on Conservation of Wetlands. Further, protection of the area around the sealing site at Kent Bay should be fostered, as this site is of great historic importance.

Agricultural developments, such as forestry and cattle and sheep grazing, are unlikely to expand greatly due to poor soils and the isolation of the island from markets. There needs to be a comprehensive feasibility study of aquaculture around Cape Barren Island.

The resolution of the Aboriginal land rights claim for the unallocated Crown Land on the island is complex and beyond the scope of this paper. Clearly, however, the issue must be resolved if a long-term management plan for the island is to be successfully formulated.

Already many tourists have been attracted to the island. It seems that the special qualities of the island, primarily its wilderness areas and isolation, are major tourism assets which so far remain underexploited. The dearth of information relating to the island has contributed to its unofficial "undiscovered" status, but this will change as the pressures increase for new recreational opportunities.

Finally, a major threat to any future developments on Cape Barren Island is the frequency of fires. Protection of homes, properties and Crown Land from the persistent fires is of major concern.

\section{ACKNOWLEDGEMENTS}

The author wishes to thank the staff of the Centre for Environmental Studies at the University of Tasmania for financial and editorial assistance in the preparation of this manuscript, and Airlie Alam for her drafting of the figures.

\section{REFERENCES}

ABBOTT, 1., 1972: Birds of Bass Strait. Pap. Proc. $R$ Soc. Tasm. 85: 197-215.

ALLEN, M.D., WHITE, P.W., JACOBS, A.R., JESSUP, H.J. \& NICHOLAS, A.l, 1978: Report of the Aboriginal Affairs Study Group of Tasmania. Tasm. Parl. J. Pap. 199(2): 1-52. 
BLACKHALL, S.A., 1986: A survey to determine waterbird usage and conservation significance of selected Tasmanian wetlands. Occ. Pap. Tasm. Natl Pks Wirdl. Serv. 14: 1-110.

BLAKE, F., 1947: The Furneaux group of islands. Unpubl. Rep. Dep. Mines Tasm.

COCKER, J.D., 1980: Regional geology of the Southern Furneaux Group. Pap. Proc. R. Soc. Tasm. 114: $49-67$

CUMPSTON, J.S., 1973: FIRST VISITORS TO BASS STRAIT. Roebuck Soc. Publication 7: 1-103.

GABRIEL, J. \& CAMPBELL, A.J., 1894: Report of expedition to Furneaux Group. Vict. Nat., 10: 179-184.

GOSCOMBE, P.W., 1965: Report on a geological reconnaissance of Cape Barren Island with proposals for drilling stanniferous leads. Unpubl. Rep. Utah Development Company, Melboume 133: $1-16$.

GUILER, E, 1961: The 1958-60 Cape Barren goose aerial survey. Еmu 61: 197-215.

HEPPER, J., BERESFORD, D., BOWMAN, S. \& RIEDER, L., 1987: TOURISM STUDY NORTH AND NORTHEAST TASMANIA. Government Printer, Hobart: 1-321.

HOPE, J.H., 1973: Mammals of the Bass Strait islands. Proc. R. Soc. Vict. 85: 163-195.

KIRKPATRICK, J.B., 1977: THE DISAPPEARING HEATH. Tasmanian Conservation Trust Inc., Hobart: 1-95.

KIRKPATRICK, J.B. \& DICKENSON, K.J.M., 1984 : VEGETATION OF TASMANIA. Forestry Commission, I-Iobart.

KIRKPATRICK, J.B. \& GLASBY, J., 1981: Salt marshes in Tasmania: distribution, community composition, and conservation. Occ. Pap. Univ. Tasm. Geog. 8: 1-62.

KIRKPATRICK, J.B. \& HARWOOD, C.E., I983: Conservation of Tasmanian macrophytic wetland vegetation. Pap. Proc. R. Soc. Tasm. 117: 5-20.

LE SOUEF, A.S., 1929: Notes on some mammals from Bass Strait islands, including a new subspecies of Pseudochirus. Aust. Zool. 5: 329-332.

McKAY, R.D., 1955: Notes on a collection of reptiles and amphibians from the Furneaux Islands, Bass Strait. Aust. Zool. 12: 160-164.
MATTHEWS, W.L., 1981: OCCURRENCES OF GEMSTONE MINERALS IN TASMANIA Department of Mines, Tasmania: 1-16.

MESIBOV, D., 1986: A GUIDE TO TASMANIAN CENTIPEDES. D. Mesibov: 1-64.

MESTON, A.L., 1947: The halfcastes of the Furneaux Group. Rec. Queen Vict. Mus. ii(1): 47-52

MURRAY-SMITH, S., 1973: Beyond the pale, the islander community of Bass Strait in the nineteenth century. Tasm. Hist. Res. Assoc. Pap. Proc. 20(4): 167-200.

ORCHISTON, D.W. \& GLENNIE, R.C., 1978: Residual Holocene populations in Bassiania: Aboriginal man at Palana, northern Flinders Island. Aust. Archaeol. 8: 127-141.

PINKARD, G.J. \& RICHLEY, L.R., 1982: LAND SCHEMES OF TASMANIA, REGION 2 Tasmanian Government Printer, Hobart: 1-66.

RUSSELL, J.A., MATHEWS, J.H. \& JONES, R., 1979 : Wilderness in Tasmania, a report to the Australian Heritage Commission. Occ. Pap. Univ. Tasm. Env. Stud. I0: 1-103.

SMITH, B.J. \& KERSHAW, R.C., 1981: TASMANIAN LAND AND FRESHWATER MOLLUSCS. Fauna of Tasmania Handbook No.5, University of Tasmania.

STANDARD, J.C., 1970: Geological evaluation of offshore drilling for tin, north east Tasmania and Cape Barren Island. Unpubl. Rep. Blue Metal Industries Mining, EL18/70 and 19/70.

VOLKER, J., 1968: Report on offshore drilling, Tasmania. Unpubl. Rep. 583, Utah Development Company-Broken Hill Proprietary, Melbourne.

WHINRAY, J.S., 1970: List of birds of Cape Barren Island, Furneaux Group, Tasmania. Tasm. Nat. 23: $1-2$.

WHINRAY, J.S., 1971: The present distribution of some mammals in the Furneaux Group, Bass Strait, Tasmania. Vict. Nat. 88: 279-285.

WHINRAY, J.S., 1977: Some plant records for the Cape Barren Wilderness Area. Tasm. Nat. 51: 9-13.

WHINRAY, J.S., 1981: An extra plant record for Tasmania. Vict. Nat 98: 80-81.

(accepted 31 March 1988) 